\title{
The Role of Innovation in Inventory Turnover Performance
}

December 2014

\author{
Hsiao-Hui Lee ${ }^{1}$, Jianer Zhou ${ }^{2}$, Po-Hsuan $\mathrm{Hsu}^{3}$
}

How a firm utilizes technological innovation to improve operations management is an important research question in today's knowledge economy but lacks empirical evidence in the literature. We use a dataset of all non-service U.S. public firms from 1976 to 2005 to examine how a firm's innovation performance is associated with its inventory turnover performance. In particular, we measure a firm's innovation performance by the ratio of its patents (either citations or counts) to its research and development (R\&D) expenditure. Our fixed-effect panel regression results indicate a positive relation between innovation performance and inventory turnover ratio, and such a relation varies across industries. By differentiating process and product innovation according to patent usages, we find that process innovation has a consistent and long-lasting effect, whereas product innovation has an immediate but short-lasting effect. We also find supporting evidence for industry spillovers by showing that firms in a more innovative industry are likely to better manage their inventory performance. Our results confirm the benefit of using innovation in logistics and operations management and point to the strategic importance of integrating technology and operations management.

Keywords: product innovation, process innovation, inventory turnover, innovation spillover.

\footnotetext{
${ }^{1}$ Corresponding author, Faculty of Business and Economics, University of Hong Kong, Hong Kong, hhlee@hku.hk, $+852-3917-1082$

${ }^{2}$ Carroll School of Management, Boston College, Chestnut Hill, MA 02467, USA, jianer.zhou@bc.edu

${ }^{3}$ Faculty of Business and Economics, University of Hong Kong, Hong Kong, paulhsu@hku.hk
} 


\section{Introduction}

Over the past decade, firms have been investing heavily in innovation to maintain their competitive advantage. Science and Engineering Indicators: 2010 (National Science Board, 2010) reports that global R\&D expenditures doubled from \$525 billion in 1996 to \$1.1 trillion in 2007. The U.S. led all other countries in R\&D expenditure, with $\$ 369$ billion in 2007. Among many innovative firms in the U.S., Apple Inc. spent $\$ 1.8$ billion in R\&D (about 2.7\% of its net sales) and filed 262 patent applications in 2010, according to the U.S. Patent and Trademark Office. Believing that "the ownership of such patents, copyrights, trademarks and service marks is an important factor in its business and that its success does depend in part on the ownership thereof”, Apple Inc. stated in its 2010 Annual Report that "[t]he Company regularly files patent applications to protect inventions arising from its research and development, and is currently pursuing thousands of patent applications around the world.” With innovative products such as iPhone and iPad and the adoption of lean operations throughout its supply chain, Apple Inc. has become one of the most valuable companies in the world. Moreover, Apple Inc. had an inventory turnover of 52.5 in 2010 (calculated from its 2010 Annual Report), much higher than the industry average of 9.1 in the HiTech segment (calculated from the Compustat dataset). Given that firms like Apple Inc. deploy more resources in innovation to sustain their competitive advantage, the way in which innovation influences inventory management performance is an important issue and calls for empirical investigation.

Previous research mainly associates a firm’s innovation with its financial performance measures (Artz et al., 2010; Gunday et al., 2011; Hirshleifer et al., 2012; Klingenberg et al., 2013), or associates a firm’s tangible assets with its operational performance measures (Gaur et al., 2005; Lin and Mithas, 2008; Shah and Shin, 2007). However, there has been little empirical work analyzing the impact of a firm's innovations on its inventory management, with the exception of the following papers focusing on specific process innovation. Balakrishnan et al. (1996) and Huson and Nanda (1995) investigate the improvement of inventory turnover after firms adopt just-in-time (JIT) manufacturing, a type of process innovation that 
moves inventories through the system as they are needed. However, to what extent product innovation (or together with process innovation) affects inventory performance remains an open question.

Instead of focusing on the effect of specific process innovation, we broadly investigate the relationship between a firm’s innovation performance (including both process and product innovation) and inventory turnover in the paper. Based on the accounting and patent data of 6,695 non-service U.S. public firms from 1976 to 2005 (the sample period is restricted by the availability of patent data), we examine the impact of innovation on inventory turnover by using fixed-effect panel regression models that consider both the firm and yearly fixed effects. Even with the control variables from the literature and the firm and yearly fixed effects, both process and product innovation exhibits a significantly positive correlation with inventory turnover, implying that a more innovative firm is likely to be more efficient in managing its inventory.

More interestingly, we examine how time and industry characteristics affect the impact of innovations on inventory turnover. First, because innovation can have profound implications for a firm's operational performance over time, we investigate the impact of innovation on inventory turnover in three consecutive years (year 0 to year 2). We find that in general innovation has a lasting but declining effect on inventory turnover, which indicates that an older invention has less influence than a newer one does. However, after differentiating "process-focused" firms from "product-focused" ones, we show that process innovation has a stronger and longer-lasting effect on inventory turnover than product innovation does. This result implies that process innovation improves inventory turnover by facilitating ordering/delivery processes or reducing inventories in the long run whereas product innovation does it mainly by stimulating sales in the short run. Second, by examining the ten industry segments, we also observe that the declining effect might be reversed if firms (e.g., in the automobile industry) produce products with a longer development and product life cycle. Finally, we inspect the role of innovation spillovers in inventory management by including the industry-level innovation variables in regressions. We find that the same-year industry-level innovation variable has a significantly positive coefficient in explaining inventory turnover, suggesting that firm-level innovation and industry spillovers play distinct 
and substantial roles in inventory management. However, spillovers do not have a long-lasting effect, indicating that, to continuously improve operational performance, firms have to rely on their own innovation capabilities instead of simply copying their competitors. It is worth noting that our results are robust to alternative innovation measures (patent citations, patent counts, or citations per count), industry classifications, time-varying industry effects (by using industry-adjusted models), and inclusion or exclusion of non-innovative firms. Thus, our empirical findings cannot be attributed only to tangible assets, firm and industry characteristics, or macroeconomic conditions.

Our research makes four significant contributions to the innovation management literature. First, not only are we, to the best of our knowledge, the first to empirically link innovation to firms' operational performance, but also, in doing so, we find that firms with better innovation performance achieve higher inventory turnover. Second, we demonstrate how innovation affects inventory turnover with the declining coefficients of the innovation variables in the three yearly windows. Third, by comparing firms intensive in process innovation with those intensive in product innovation, we find that process and product innovations play distinct roles in inventory turnover performance. This result provides new insights into why firms should devote resources to improving their processes in order to achieve superior inventory performance in the long run. Fourth, we show the positive effect of industry-level innovation on firmlevel inventory turnover, which supports the idea of innovation spillovers and adds to the literature of technology externalities from an operations management perspective.

\section{Theory and hypothesis}

When applying innovations in their businesses, firms could achieve higher inventory turnovers by either generating more sales in the market or by reducing inventories in the production process. Manu and Sriram (1996) suggest a need to examine innovation in multiple dimensions, e.g., innovation type. We

therefore first motivate our hypothesis by discussing how the two types of innovation-product innovation and process innovation—might be associated with inventory turnover. 


\subsection{Product innovation and inventory turnover}

Product innovation — the introduction of a new or improved product—mainly affects inventory turnover by identifying/satisfying new customer demand and hence generating more sales. The Bass diffusion model (Bass, 1969) illustrates the demand pattern for a new product over the product life cycle. Thus, inventory turnover is mostly determined by how the firm matches its capacity and inventory with the diffusion process. According to Norton and Bass (1987) that extends the Bass model to incorporate successive generations of technology, if a firm invents new products on a regular basis, the same Bass diffusion process is valid for each generation. This result implies that the effect of each product innovation on inventory turnover could be repetitive and consistent, and a firm might achieve a more accurate demand forecast for its new products over successive innovations by refining its coefficient estimates of innovation and imitation in the Bass diffusion model. As a result, changes in market demand can result in high inventory turnover if the firm uses advanced techniques to promptly adjust its production line and supply chain according to the more precise demand forecast. Rodgers (1995) proposes the diffusion of innovation theory and argues that relative advantage, technical compatibility, and technical complexity can affect the rate of innovation adoption. Following this theory, Zhang et al. (2014a) show that firms (e.g., designing social virtual world) can accelerate sales of a new product by simplifying its configuration and reducing customer learning. Moreover, although an increase in sales leads to an increase in inventory, such increase is usually less than proportional because of the economy of scale (Olivares and Cachon, 2009). It follows that product innovation is positively associated with inventory turnover.

However, as product innovation affects inventory turnover mainly by improving sales, considering fast new-product introductions and short product life cycles in recent decades, we hypothesize that the impact of product innovation on inventory turnover can be short-lived, that is, product innovation may affect sales significantly only in the same year. We state our first hypothesis formally: 
Hypothesis 1: Product innovation is positively correlated with inventory turnover; its effect on inventory turnover is immediate but short-lasting.

\subsection{Process innovation and inventory turnover}

Process innovation affects inventory turnover mainly by either facilitating orders and sales or reducing the inventory level in the production process. The former effect (i.e., facilitating orders and sales) receives support from prior studies showing that inventions in coordinating supply-chain participants result in growing and more cost-efficient sales (Holmstrom, 1998), fewer out-of-stock problems (Kaipia and Tanskanen, 2003), and more efficient replenishment (Li, 2012). Such an effect can also be illustrated by the following examples from the patent database. Stamps.com Inc. filed a patent $($ No. $7,035,832)$ in 2004 for its system and method of automatically providing information of shipping and transportation fees to its customers. Kroger, a retail food chain, was granted a patent $($ No. 7,124,098) in 2006 for its shopping system that permits a customer to submit online orders for items/services from a store that serves both walk-in and online customers. This system allows customers to change their shopping decisions even after submitting their orders, and allows customers to pick up their orders. Both process innovations can potentially generate more sales by improving customer shopping and ordering experience, which in turn lead to higher inventory turnover.

We next elaborate on the latter relation (i.e., reducing the inventory level) from three perspectives: flow time, defects, and safety stocks. If a process innovation (such as an improvement in the manufacturing process) is successful, it can reduce production cost, increase production efficiency, and/or improve product quality. Process innovation will result in improved performance if it leads to more flexible, responsive, coordinative, and team-oriented work at the operational level, as suggested in the literature. ${ }^{4}$ For example, the patent (No. 7,020,594) granted to Sony Corporation in 2006 introduced an

\footnotetext{
${ }^{4}$ First, flow time - the time required to transform raw materials into finished products—-has been a key indicator of the efficiency of a production system since the late 19th century. According to Little's law (Little, 1961), for a given throughput rate, if a firm shortens flow time by modifying its production process, the inventories of raw materials, works-in-progress, and finished products will decrease and inventory turnover will increase. Second, streamlining
} 
electronic kanban worksheet to integrate the preventive maintenance scheduling and kanban-based WIP control. Siemens Electronics Assembly Systems, Inc. filed the patent (No. 7,321,803) to perform quick changeovers on assembly lines. The patent (No. 8,321,049) filed by the Procter \& Gamble Company in 2009 introduced a new flexible manufacturing system that allows a machine to produce more than one product during a single run, which in turn shortens the flow time and improves production efficiency.

Lowering inventories through process innovation could also have a secondary effect on sales. If a firm can manage to reduce waste, defects, or buffer in its process, the cost savings will allow the firm to reduce its price which can stimulate more customer demand. All of these effects contribute to higher inventory turnover. Our view is partially supported by Sadikoglu and Zehir (2010) which shows a positive correlation between total quality management (TQM) practices—a type of process innovationand firm performance including operating performance, quality performance, and customer satisfaction in Turkish firms.

Process innovation can also change the way that firms share information and knowledge within or even across organizations. Tsui (2005), Zhang et al. (2012), and Zhang et al. (2014b) show that firms invent new technologies (e.g., knowledge discovery system, E-collaboration tools, enterprise information portal, etc.) to encourage and facilitate knowledge sharing and improve process efficiency. If a firm

the production process can reduce mistakes and defects on the production line, save waste resulting from discarded defective parts or products, and enhance the consistency of product quality. For example, JIT, the widely used revolutionary system of managing production processes, has been successful in eliminating defects (Lieberman and Demeester, 1999). By lowering defect rates, a firm can reduce the amount of inventories required to buffer against repair and rework. Consistent product quality also results in fewer returns or exchanges from customers, another reason to lower the inventory level. Furthermore, "high quality at the source" eliminates extra time required for extensive inspections and potential repairs, which reduces the total flow time. As discussed earlier, shorter flow time leads to fewer inventories in the process. Third, a major benefit of process innovation is reduced flow time and, thus, reduced production lead time. Improving processes also reduces lead-time variability. With a shorter and more consistent lead time, a firm will set a lower reorder point (the inventory level at which the firm places its production orders) in a continuous review system (Stevenson, 2011). It also means that the firm will carry less safety stock as a buffer against potential stockouts for a given service level. Reducing the reorder point and the safety stock will improve inventory turnover. 
operates and carries inventories in multiple locations, it can virtually pool its inventories and hence reduce safety stock by sharing inventory availability information (Anupindi et al., 2011). Furthermore, it is well documented that information asymmetry causes the bullwhip effect, which is characterized by larger inventory variability for upstream firms in the supply chain. Adopting new technologies to share information and knowledge in the supply chain, firms can better synchronize their processes and carry fewer inventories throughout the entire chain.

Moreover, process innovation may have a gradual and lasting effect on reducing inventories because it often takes time to implement process changes. Following the Plan-Do-Check-Act (PDCA) cycle in process improvement, firms may experiment with a new process innovation on a limited basis as a pilot. Depending on the experiment results, they may choose to roll out the new process in the form of projects from one department to another, from one plant to another, or from one store to another. Yuan et al. (2009) argue that project-based teamwork requires team-internal and team-external coordination and that team-external coordination usually takes more time. A number of papers including Kraut and Streeter (1995), Nidumolu (1995), and Faraj and Sproull (2000) discuss the challenges of coordination, and Yuan et al. (2009) recently show that implicit knowledge (i.e., personal, hard to formalize, and difficult to communicate) sharing has a significant positive impact on coordination effectiveness. These results suggest that it can take time to transfer knowledge of a new process innovation from one team to another or from one location to another, so the effect of process innovation on operational performance can also be gradual. Therefore, we test the relation between innovation and inventory turnover in three consecutive yearly windows. On the basis of the above observations in industry and of evidence in the literature, we propose our second hypothesis as follows.

Hypothesis 2: Process innovation is positively correlated with inventory turnover; its effect on inventory turnover is long-lasting.

We acknowledge that product innovation and process innovation may be intertwined (Bhoovaraghavan et al., 1996; Ettlie, 1995; Schmidt and Porteus, 2000); for example, manufacturing a new product may require a change in process. In fact, a lot of firms innovate in both products and 
processes; Apple, Inc. exhibits its capability in streaming processes (process innovation) as well as its capability in new product innovation. In the past decades, many firms have adopted flexible manufacturing system (FMS) to better respond to uncertain demands. Oke (2013) shows a positive relationship between the interactive term of mix flexibility and labor flexibility and product innovation. More recently, Wu et al. (2013a) show that cloud manufacturing (CM) exhibits great potential to share a collection of distributed manufacturing resources to form temporary and reconfigurable production processes. Because CM, which is a process innovation, can pool the best possible resources in a timely fashion, it allows for more efficient and collaborative state-of-the-art product design and innovation in response to uncertain customer demand (Wu et al., 2013b). Although product innovation and process innovation can be intertwined, our hypothesis in the overall impact of innovation on inventory turnover should hold, as both types of innovation have a positive correlation with inventory turnover. Thus, we propose:

Hypothesis 3: Innovation is positively correlated with inventory turnover.

\subsection{Industry spillover and inventory turnover}

Finally, we examine the effect of innovation spillovers on inventory management. The economics literature provides empirical evidence that firms benefit from the research activities of competitors or nonprofit institutes; such outside research raises output and productivity (Evenson and Kislev, 1973; Jaffe, 1988), increases profitability (Matolcsy and Wyatt, 2008), and reduces production costs (Bernstein and Nadiri, 1989). Using patent data, Meyer and Subramaniam (2014) also argue that it may take longer to realize an innovation's technical value which can spill over to other firms in the industry and is not always retained by the original innovator. Whether these spillover effects also apply to inventory management has not been explored to our knowledge. We argue that because industry-level innovation affects firmlevel innovation when a firm learns, copies, or imitates its competitors in the same industry, industrylevel innovation should also have an overall impact on the firm's operational performance, including inventory turnover. This leads us to hypothesize that there is a positive relation between industry-level 
innovation and firm-level inventory turnover, controlling for other characteristics, including firm-level innovation.

Hypothesis 4: Industry-level innovation is positively correlated with inventory turnover.

\section{Data and methods}

Using the Standard \& Poor's Compustat database as our source, we collected accounting data (annual net sales, fixed assets, cost of goods sold, total inventories, and number of employees) from all U.S. public firms listed on NYSE, AMEX, and NASDAQ over the period 1976-2005. We then retrieved the patent records of these companies from the updated NBER patent dataset developed by Hall et al. (2001), which consists of detailed information—patent assignee names, number of patents, number of citations received by each patent, filing dates, issue dates, and the Compustat-matched identifiers—on all U.S. patents granted annually by the U.S. Patent and Trademark Office (USPTO) between 1976 and 2005. We choose to use patent data in this research because the number of patents filed by each firm every year (patent count) indicates the quantity of innovation output, whereas the number of citations to an individual patent (citation count) indicates the quality of that specific innovation. Hall (1992) lists patents as one of the intangible resources and claims that "patent data bases constitute one of the richest, albeit esoteric, information crops which it is possible to harvest.” It is also noted that patent data are advantageous in measuring innovation output from several perspectives: first, patents are realized inventions ready to be utilized in operations; second, patents are exclusive property rights protected by the government and have been actively traded in markets (Lev, 2001); finally, although firms can outsource R\&D overseas, they still need to file U.S. patents for intellectual property protection in the U.S. due to the territorial principle in patent laws (Hsu, 2009). All these support that patent data are a more precise proxy of U.S. firms' innovation output.

The NBER patent dataset does not specify whether a patent belongs to process or product innovation. To classify all patents in our dataset into process or product innovations, we adopt the framework used by Scherer (1982, 1984) and Cohen and Klepper (1996a, 1996b), together with the U.S. Patent Classification 
System (USPC) that categorizes technologies into about 400 three-digit classes. In the framework a patent is classified as process innovation if its industry of origin is the same as its industry of use; otherwise it is product innovation. It is worth noting that most firms in our dataset have a portfolio of process and product innovations, so we calculate a ratio of a firm's number of patents classified as process innovation to its total number of patents. After sorting this ratio of all firms in a descending order, we divide the firms equally into three groups: the firms in the top group have more process innovations on average over the period of the time series and, thus, are process-focused; those in the bottom group have less process innovations, or equivalently, more product innovations on average and, thus, are product-focused; and those in the middle group are well balanced. We test Hypotheses 1 and 2 by comparing the three groups, and we test Hypothesis 3 by using the union of the three groups.

\subsection{Inventory turnover and innovation variables}

Following Standard \& Poor’s Compustat User’s Guide, we define inventory turnover as the ratio of a firm's cost of goods sold to its average inventory in the same year, that is, $I T_{\text {sit }}=C G S_{\text {sit }} /\left(0.5 I N V_{\text {sit }}+\right.$ $\left.0.5 I N V_{s i, t-1}\right)$, where $I N V_{\text {sit }}$ and $C G S_{\text {sit }}$ denote the total inventory and the cost of goods sold of firm $i$ in segment $s$ of year $t$, respectively.

Defining industry segment $s$ is important for the model specification and robustness test. We follow the classification of Fama-French 10 and 48 industry segments to reorganize all four-digit standard industry classification (SIC) codes. For example, by grouping firms with SIC codes of 5000-5999, 72007299, and 7600-7699, Fama and French define Shops to include wholesale and retail firms, along with certain services, such as laundries and repair shops, in the Fama-French 10 industry segments (see Table 1 for more details). Although we used the classification by Fama and French (1997), we also robustly tested all of our models by grouping firms by the first two or three digits of their SIC codes, and the results are consistent with those reported in the paper.

Some firms (e.g., pharmaceutical companies) invest more in innovation and consequently have more patents than others (e.g., supermarkets). To measure innovation performance across firms, we divide 
a firm's patents by its R\&D expenditure. The citation-based innovation performance is thus defined as IEcite $_{\text {sit }}=\left(1+\right.$ Cite $\left._{\text {sit }}\right) / R D_{s i, t-1}$, in which Cite $_{\text {sit }}$ is the number of cumulative citations defined as the number of subsequent patents (granted by the end of 2006) that cite firm i's patents filed in year $t$, and $R D_{s i, t-1}$ is its $R \& D$ expenditure in year $t-1$. Cumulative citations have been commonly used as a proxy that reflects both quantity and quality of firm i's innovation output and appropriately captures the economic value associated with its innovation activities (Trajtenberg, 1990; Hall et al., 2005). We then scale cumulative citations by R\&D expenditure, following Gu (2005) and Hirshleifer et al. (2012). We use the adjusted cumulative citations from the NBER dataset that correct for the time-trend bias due to the citation lag. In particular, the NBER dataset addresses the issue that old patents inherently receive more citations than new patents by estimating the citation-lag distribution (i.e., the fraction of lifetime citations). Prior empirical studies indicate that the average lag in the relation between patent application and $R \& D$ expenditure is relatively short (Hausman et al., 1984; Hall et al., 1986). We therefore use a one-year lag to accommodate this effect.

It is worth noting that for those firms with no record in the NBER dataset, that is, firms that never filed any successful patent applications, annual patents are set to zero. In the numerator of IEcite sit $_{\text {, we }}$ add one to the patent citations so that we can include zero-patent firms in the panel regression models (Lerner, 1994) after log-transforming the variable. Such log-transformation is necessary because the distribution of firms' patents is skewed to the right. For robustness purposes, we also run all of our regressions by excluding firms without any patents over the period 1976-2005 because they could be considered not innovative. The results remain fairly consistent and, therefore, are not reported in the paper.

We also measure innovation by patent counts, i.e., Count $_{\text {sit }}$, which firm $i$ successfully filed in segment $s$ of year $t$. The count-based innovation performance is thus defined as IEcount $_{\text {sit }}=$ $\left(1+\right.$ Count $\left._{s i t}\right) / R D_{s i, t-1}$. Patent counts evaluate a firm's innovation output from the quantity perspective, whereas patent citations reflect the quality of its innovation output. We test our regression models with 
both innovation variables and the results are very consistent, so our empirical inferences are robust with respect to the measures of innovation performance.

\subsection{Control variables}

Gaur et al. (2005) show that inventory turnover negatively correlates with gross margin and positively correlates with capital intensity and sales surprise in the retail industry. They argue that changes in inventory turnover could be caused by marketing strategy (e.g., promotion and discount), investments in tangible assets (e.g., new warehouses or hardware), or demand shocks (e.g., unexpectedly high or low demand).

To control for these effects in our empirical analysis, we include their variables in our empirical tests. Specifically, gross margin is defined as $G M_{\text {sit }}=\left(S_{\text {sit }}-C G S_{\text {sit }}\right) / S_{\text {sit }}$, in which $S_{\text {sit }}$ is the net sales of firm $i$ in segment $s$ of year $t$; capital intensity is defined as $C I_{\text {sit }}=G F A_{\text {sit }} /\left(I N V_{\text {sit }}+G F A_{\text {sit }}\right)$, in which $G F A_{\text {sit }}$ denotes the fixed assets of firm $i$ in segment $s$ of year $t$; and sales surprise is defined as $S S_{\text {sit }}=$ $S_{\text {sit }} /$ Sales forecast sit $_{\text {. Sales forecast }}$ sit is computed based on the Holt's linear exponential smoothing method (i.e., Sales forecast sit $=L_{s i, t-1}+T_{s i, t-1}$, in which $L_{s i, t-1}$ and $T_{s i, t-1}$ are smoothed series defined as $L_{s i t}=\alpha S_{s i t}+(1-\alpha)\left(L_{s i, t-1}+T_{s i, t-1}\right)$ and $T_{s i t}=\gamma\left(L_{s i t}-L_{s i, t-1}\right)+(1-\gamma) T_{s i, t-1}$, with $\alpha=\gamma=0.75)$

Furthermore, Lieberman and Demeester (1999) demonstrate that inventory level is negatively associated with labor productivity for 52 Japanese automotive companies. Following their results, we include labor productivity as the fourth control variable in our empirical models. Firm $i$ 's labor productivity (LP) is defined as the value added per employee: $L P_{\text {sit }}=\left(S_{s i t}-C G S_{\text {sit }}\right) / N E_{\text {sit }}$, in which $N E_{\text {sit }}$ is the number of employees of firm $i$ in segment $s$ of year $t$. The value added is approximated by the net sales less the cost of goods sold (Lieberman and Demeester 1999); hence, LP can also be interpreted as the gross profit per employee. Hall (1992) uses the increase in sales per employee as an alternative productivity measure. We did not adopt Hall's measure because the increase in sales could be 
caused by a booming market little related to labor productivity. Because the value added per employee also takes costs into consideration, we view it as a better reflection of the use of human capital.

\subsection{Summary statistics}

Merging the Compustat dataset with the NBER patent dataset for the sample period 1976-2005 results in 600,367 firm-year observations. Since this study focuses on inventory turnover performance, we eliminate from the original Compustat dataset those firms that mainly provide services and may not carry physical inventories, after which 352,338 firm-year observations remain. (Following the grouping rules of Fama-French 48 industry segments, we omit firms in entertainment, healthcare services, construction, utilities, telecommunication, personal services, business services, transportation, restaurants, banking, insurance, real estate, financial trading, and others.) Among these, 46\% report inventory levels and cost of goods sold, $43 \%$ report number of employees, and $24 \%$ report R\&D expenditures. As a result, our panel dataset for empirical tests contains 50,640 firm-year observations of 6,695 firms across all non-service industries.

Table 2 shows summary statistics of the variables by the Fama-French 10 industry segments. It lists the number of firms, the number of observations, and the mean and standard errors of each variable in each industry segment. The innovation performance varies widely across industry segments. Average patent citations range from 15.92 in the Shops segment to 387.02 in the Energy segment, whereas the average IEcite ranges from 9.76 in the Consumer Non-durables segment to 27.41 in the Healthcare segment. Although the Energy segment, which includes oil, gas, and coal extraction and products, has the highest average patent citations per firm, its average IEcite is ranked second to the last. This implies that innovation costs vary across industries, which prompts us to control for this heterogeneity when constructing the innovation variables. Note that the Telecommunication and the Utilities segments mainly provide services and, hence, are not reported in Table 2.

Table 3 presents correlations of logarithmic values of the independent and dependent variables.

The correlations among $\log \left(\right.$ IEcite $\left._{\text {sit }}\right), \log \left(\right.$ IEcite $\left._{s i, t-1}\right)$, and $\log \left(\right.$ IEcite $\left._{s i, t-2}\right)$ are high $(72.5 \%-79.5 \%)$ 
because they are yearly lagged variables. $L P_{\text {sit }}$ and $G M_{\text {sit }}$ share the same numerator. Thus, the correlation between $\log \left(L P_{\text {sit }}\right)$ and $\log \left(G M_{\text {sit }}\right)$ is reasonably high (59.5\%). To test if the high correlation suggests multicollinearity, we compute the variance inflation factors (VIFs), which are 3.09, 3.73, 3.49, 1.77, 1.64, 1.01, and 1.01 for $\log \left(\right.$ IEcite $\left._{\text {sit }}\right), \log \left(\right.$ IEcite $\left._{\text {si,t-1 }}\right), \log \left(\right.$ IEcite $\left._{\text {si,t-2 }}\right), \log \left(L P_{\text {sit }}\right), \log \left(G M_{\text {sit }}\right), \log \left(C I_{\text {sit }}\right)$, and $\log \left(S S_{\text {sit }}\right)$, respectively. These low VIFs suggest that multicollinearity is not significant among the independent variables. We also test that the univariate and full regression models do not exhibit erratic changes in the coefficient estimates, which confirms that multicollinearity is not an issue. In unreported tests, we try LP with a one-year lag to alleviate the concern of its high correlation with gross margin and obtain similar results.

\subsection{Model specification}

We propose the following panel regression model to test whether or not innovation explains inventory turnover, controlling for labor productivity, gross margin, capital intensity, sales surprise, firm fixed effect, and yearly fixed effect:

$$
\begin{gathered}
\log \left(\text { IT }_{\text {sit }}\right)=a^{1} \log \left(\text { IEcite }_{\text {sit }}\right)+a^{2} \log \left(\text { IEcite }_{\text {si,t-1 }}\right)+a^{3} \log \left(\text { IEcite }_{\text {si,t-2 }}\right)+a^{4} \log \left(\text { LP }_{\text {sit }}\right)+ \\
a^{5} \log \left(G M_{\text {sit }}\right)+a^{6} \log \left(C I_{\text {sit }}\right)+a^{7} \log \left(S S_{\text {sit }}\right)+F_{i}+T_{t}+\varepsilon_{\text {sit }}
\end{gathered}
$$

in which $a^{1}$ to $a^{7}$ are the coefficients of the independent variables, and IEcite can be replaced with IEcount to test the robustness. $F_{i}$ is the time-invariant, firm-specific fixed effect for firm $i$, and $T_{t}$ is the time-specific fixed effect for year $t$. To examine whether innovation has a lagged effect on inventory turnover, we test our model in three yearly windows (more lagged innovation variables are no longer significant and hence are not included in the model specification); for example, with the variable $\log \left(\right.$ IEcite $\left._{s i, t-2}\right)$, we test whether inventory turnover this year is affected by innovations from two years ago.

We log-transform our main explanatory variables in Equation (1) because the skewness

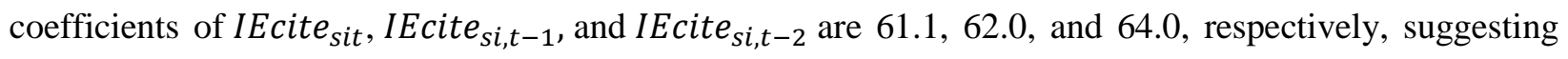
that a simple linear regression model may be inappropriate. After the log-transformation, the skewness 
coefficients of $\log \left(\right.$ IEcite $\left._{\text {sit }}\right), \log \left(\right.$ IEcite $\left._{s i, t-1}\right)$, and $\log \left(\right.$ IEcite $\left._{\text {si,t-2 }}\right)$ become $-0.38,-0.41$, and -0.46 , respectively. The distributions of these log-transformed explanatory variables are much closer to normal, so they are more appropriate for empirical tests and are expected to provide more reliable statistical inferences.

We recognize that inventory turnover could be correlated with factors not included in Equation (1) or in our dataset, such as firm size, managerial talents, inventory policy, accounting policy, etc. To correct for potential bias due to omitted firm-specific factors (if any) that may drive inventory performance, we use the fixed-effect model to compare average inventory turnover across firms over the period of the time series. The fixed-effect model controls for the heterogeneity across firms by including the firm-specific fixed effect $F_{i}$. In addition, the Hausman test confirms that a fixed-effect model is preferred to a randomeffect model for our dataset.

Also recognizing that inventory turnover can be affected by macroeconomic factors, such as economic conditions, Federal Reserve’s monetary policies, business cycles, etc., we include the timespecific fixed effect $T_{t}$ to control for time-varying heterogeneity. The Wald tests of simple and composite linear hypotheses of yearly dummy variables also suggest that the time-specific fixed effects should be considered in our regression model. We perform the modified Wald test for segment-wise heteroskedasticity and the Wooldridge test for autocorrelation, and confirm that both issues do exist in our panel dataset. Therefore, our statistical inferences must be based on robust standard errors corrected for heteroskedasticity and autocorrelation.

Finally, innovation spillover may play an important role in firm-level inventory management, due to the positive externalities of innovation. We propose the following model to include industry-level innovation variables and examine whether or not a firm benefits from other firms' inventions in the same industry from an operational perspective:

$$
\begin{aligned}
\log \left(\text { IT }_{\text {sit }}\right)= & b^{1} \log \left(\text { IEcite }_{s t}\right)+b^{2} \log \left(\text { IEcite }_{s, t-1}\right)+b^{3} \log \left(\text { IEcite }_{s, t-2}\right)+ \\
& b^{4} \log \left(\text { IEcite }_{\text {sit }}\right)+b^{5} \log \left(\text { IEcite }_{s i, t-1}\right)+b^{6} \log \left(\text { IEcite }_{s i, t-2}\right)+b^{7} \log \left(\text { LP }_{\text {sit }}\right)+
\end{aligned}
$$




$$
b^{8} \log \left(G M_{\text {sit }}\right)+b^{9} \log \left(C I_{\text {sit }}\right)+b^{10} \log \left(S S_{\text {sit }}\right)+F_{i}+T_{t}+\varepsilon_{\text {sit }}
$$

in which $I E$ cite $_{s, t-j}$ is the industry-level innovation variable for segment $s$ of year $t-j$ for $j=0,1,2$. To classify the segments, we adopt the Fama-French 48 industry classification.

\section{Empirical results}

Table 4 shows the regression results for Equations (1). Columns (a) to (d) show the coefficient estimates for the three groups and all firms in the dataset, respectively. The positive coefficients of the citationbased innovation variables are statistically significant (with $p$-values mostly less than $1 \%$ ) for the processfocused firms in Column (a) whereas the positive coefficient is statistically significant only in the same year for both the product-focused firms in Column (b) and the balanced firms in Column (c). These results support Hypotheses 1 and 2 that product innovation has an immediate but short-lived effect on inventory turnover whereas process innovation has a consistent and lasting effect. Column (d) indicates that the coefficients of the innovation variables of all firms are positive and statistically significant with $p$ values mostly less than $1 \%$, which strongly supports Hypothesis 3 that innovation is positively associated with inventory turnover. In addition, the coefficients of the innovation variables exhibit a decreasing trend, from 0.009 in year 0 to 0.005 in year 2 in Column (d). These results suggest that the older the innovations are, the less impact they have on inventory turnover performance. To ensure our results' robustness, we perform robustness tests by employing different model specifications or variables, including the countbased measure, i.e., IEcount. Columns (e) to (h) show that the positive and significant results are similar to those from the citation-based measures.

In the model, the coefficient estimate of each log-transformed variable gives the elasticity of inventory turnover with respect to that variable. For example, if we take the standard deviation of the logtransformed variable into consideration, we find that one standard deviation increase in $\log \left(I E c i t e_{s i t}\right)$, $\log \left(\right.$ IEcite $\left._{s i, t-1}\right), \log \left(\right.$ IEcite $\left._{s i, t-2}\right), \log \left(L P_{\text {sit }}\right), \log \left(G M_{\text {sit }}\right), \log \left(C I_{\text {sit }}\right)$, and $\log \left(S S_{\text {sit }}\right)$ changes the logarithm of inventory turnover by $0.037,0.032,0.033,0.292,-0.310,0.180$, and 0.111 , respectively, for

process-focused firms in Column (a) in Table 4. (The standard deviations of log (IEcite sit $_{\text {) }}$, 
$\log \left(\right.$ IEcite $\left._{\text {si,t-1 }}\right), \log \left(\right.$ IEcite $\left._{\text {si,t-2 }}\right), \log \left(L P_{\text {sit }}\right), \log \left(G M_{\text {sit }}\right), \log \left(C I_{\text {sit }}\right)$, and $\log \left(S S_{\text {sit }}\right)$ are 2.33, 2.26, 2.20, 0.95, 0.53, 0.53, and 0.43, respectively.) Even after we include the four control variables, which are well documented in the literature, the effect of innovation on inventory turnover is still strongly significant and relatively comparable.

The positive effect of innovation on inventory turnover also has implications for investment returns. In an unreported table, we regress return on assets (ROA) and return on equity (ROE) of firm $i$ in segment $s$ of year $t$ on $\log \left(I T_{\text {sit }}\right), \log \left(\right.$ IEcite $\left._{\text {sit }}\right), \log \left(\right.$ IEcite $\left._{s i, t-1}\right), \log \left(\right.$ IEcite $\left._{s i, t-2}\right), \log \left(\right.$ LP $\left._{\text {sit }}\right)$, $\log \left(G M_{s i t}\right), \log \left(C I_{s i t}\right), \log \left(S S_{s i t}\right)$, the firm-specific fixed effect $F_{i}$, and the time-specific fixed effect $T_{t}$. We find a significantly positive relation between profitability (measured by ROA or ROE) and innovation performance measured by IEcite. Specifically, one standard deviation increase in $I E c i t e_{\text {sit }}, I E c i t e_{s i, t-1}$, and IEcite $_{s i, t-2}$ is associated with ROA increase of $0.487 \%, 0.411 \%$, and $0.443 \%$, respectively. In addition, one standard deviation increase in $I E c i t e_{s i t}, I_{E c i t e} s i, t-1$, and IEcite $_{s i, t-2}$ is associated with ROE increase of $0.704 \%, 0.531 \%$, and $0.867 \%$, respectively. More importantly, we find an even stronger effect for the process-focused firms, supporting the real value for innovation in process management.

Motivated by the different effects of process and product innovation, we further conduct a subgroup empirical analysis by using the Fama-French 10 industry classification (see Table 1 for details). Not only does the subgroup analysis serve as another robustness check for our earlier findings, it also explains the differences between industry segments. A summary of the regression results is shown in Table 5. Since we eliminate service firms from our dataset, no observations exist in the Telecommunication segment (telephone and television transmission) or the Utilities segment (electric, gas, natural gas, and water services).

The Shops segment, after the omission of service firms, mainly includes retailers and wholesalers, whereas the HiTech segment mainly produces computers and electronic equipment. Our results show that innovation has a greater effect on inventory turnover for the Shops segment than for any other segments. The significant coefficients of $\log \left(\right.$ IEcite $\left._{\text {sit }}\right)$ and $\log \left(\right.$ IEcite $\left._{s i, t-1}\right)$ are 0.053 and 0.022 , respectively, for 
the Shops segment in Table 5, much higher than the coefficients for the other segments. In addition, the significant coefficient of $\log \left(\right.$ IEcite $\left._{\text {sit }}\right)$ is only 0.009 for the HiTech segment. If firms in the Shops (HiTech) segment can be considered as a proxy for firms that produce more process (product) innovations (which has been verified by our dataset), the comparison of these two segments echoes our empirical findings in the comparison between product and process innovation. Product innovation tends to affect inventory turnover in a limited time span while process innovation may have greater and longer-lasting effect.

Among the other segments, the results for Consumer Non-durables, Consumer Durables, Manufacturing, and Healthcare are mostly significant, whereas the results for Energy are insignificant. On the one hand, for the Consumer Durables segment (e.g., automobile firms), it may require more time to implement innovations to improve their products which have a longer development and product life cycle, so the coefficients of $\log \left(I_{E c i t e}\right.$ si,t-1 $\left._{1}\right)$ and $\log \left(I_{E c i t} e_{s i, t-2}\right)$ are positive and significant. On the other hand, great heterogeneity might cause the negative coefficients in the Consumer Non-durables segment (food, tobacco, textiles, apparel, leather, and toys), which is not consistent with our general findings. Our data show that the average number of patent citations for the entire segment is 34.69 , and for the Toy, Tobacco, Textiles, Apparel, and Food industries, the average is 365.35, 8.29, 19.44, 25.37, and 33.44, respectively.

The insignificant results are also intriguing. Although the Energy segment (oil, gas, and coal extraction and products) has a very high average of 387.02 patent citations, its innovation does not significantly correlate with inventory turnover. The fundamental production processes from oil drilling to refinery to delivery have not changed much over the past several decades, and it is very costly for firms in this segment to manipulate a continuous production system whose output depends largely on the crude oil supply instead of being responsive to demand. Furthermore, firms often trade future contracts of crude oil and natural gas in major financial markets around the world and adjust their inventories sensitive to the price volatility. It may be these unique characteristics rather than innovative activities that affect firms' inventory turnover in this segment. 
Finally, Table 6 supports a positive spillover effect of industry-level innovation on inventory turnover. The coefficient of the industry-level innovation variable is 0.012 in the same year at the $5 \%$ confidence level in Column (a). It is worth noting that the spillover effect is no longer significant beyond the same year, indicating that such effect on a firm's operational performance is less persistent than are its own innovations. In addition, the coefficients of the firm-level innovation variables remain significantly positive, confirming the impact of firm-level innovation on inventory turnover. The observation that both industry- and firm-level innovation variables have significantly positive coefficients suggests that industry spillovers and firm-level innovations play distinct and substantial roles in explaining inventory turnover, thus validating Hypothesis 4. We also test Equation (2) by the three firm groups, and the results can be found in Columns (b) to (d). The coefficient of the industry-level innovation variable is positive and significant in the same year for the process-focused firms. Compared with the insignificant coefficients for either the product-focused or the balanced firms, this result suggests that the industry spillover effect could be mainly attributed to process innovations.

\section{Discussion and conclusions}

Our empirical results offer several managerial insights. One is that firms' innovative activities do affect their operational performance, namely, there exists a positive correlation between innovation performance and inventory turnover. Product innovation can usually stimulate customer interest and generate more demand. Because the increase in sales usually exceeds that in inventory (Olivares and Cachon, 2009), inventory turnover improves with product innovation. Knowing the demand pattern from the classic Bass diffusion model, firms could also smartly adjust their capacity or negotiate outsource contracts to minimize the mismatch between supply and demand and, therefore, achieve superior inventory turnover performance. Moreover, firms investing in process innovation could generate more sales by improving customer shopping/ordering experience. Process innovation reduces flow time and lead time in the production processes and, as a result, the inventories of raw materials, works-in-progress, and finished goods would decrease. Reducing production lead time and its variability allows firms to lower the reorder point as well as the safety stock (which buffers against stockouts). Because improving production 
processes could also lead to higher and more consistent product quality, firms could expect fewer inventories caused by mistakes, defects, returns, and exchanges. The resulting savings can allow firms to reduce their prices and sell more products. Overall, our results suggest that firms with better innovation performance are able to have higher inventory turnover.

We also observe that process innovation affects inventory turnover performance more strongly than does product innovation. By grouping firms according to whether they produce more process or product innovations, we show that the coefficients of the innovation variables for the process-focused firms are significantly higher than those for the product-focused firms, indicating a stronger effect of process innovation. More interestingly, while product innovation can improve inventory management performance from the demand side, such effect may not be long-lasting. In contrast, the effect of process innovation is more consistent over multiple years probably because it usually takes time to implement process innovations and firms often roll out new processes by phase. To the best of our knowledge, we are the first to show this intriguing new pattern by distinguishing process and product innovations. Firms should probably devote more resources to improving their processes in order to achieve better inventory performance in the long run.

Another insight comes from the decreasing trend in the coefficients of the innovation variables, which indicates that the effect of innovation on inventory turnover decreases over time. The decreasing coefficients could be partially explained by the diffusion of product innovation, in which demand for a new product starts to decline after reaching its peak. As the demand drops, the sales of this product contribute less to a firm's overall business, leading to a weaker influence on inventory turnover. In particular, since product life cycles can be shortened by technology advancement, many new products could reach their peak demand level within the same year of market introduction, which is evidenced by our result that the coefficient of the innovation variable is significant only in the same year for the product-focused firms. In its 2010 Annual Report, Apple Inc. stated that "[d]ue to the fast pace of innovation and product development, the Company's products are often obsolete before the patents related to them expire, and sometimes are obsolete before the patents related to them are even granted.” 
Although the pooling regression of all firms in our dataset exhibits a decreasing trend, we also observe the non-decreasing coefficients in the Consumer Durables segment, whereas the decreasing coefficients remain significant in the Shops and Healthcare segments. As the Consumer Durables segment produce products with a longer development and product life cycle, it is not surprising that the effect of innovation in this segment differs from that in the HiTech segment in which the coefficient is only significant in the same year; for example, it might require more component inventions and a longer time to build a new car model than a new computer or electronic equipment.

A third insight offered by our empirical evidence is that industry innovation spillovers also affect a firm's inventory performance. When a new process innovation emerges, firms in the same industry have incentives to copy each other to stay competitive. In fact, it is relatively easy for firms to learn from each other and imitate, if not copy, process innovations. Everyone benefits from the new processes by streamlining their businesses and reducing inventories. Our results show that the spillover effect is significant only for the process-focused firms. This can be partially explained by the fact that product innovations are more strictly protected by law. Our results also indicate that the spillover effect is less persistent than the effect of the firm's own innovations, suggesting that firms should continue to rely on their own innovative capability to generate more sales and/or improve their processes. Moreover, managers and industry analysts should be cautious in interpreting a change in a firm's inventory turnover performance because it may be affected by the innovative capability of the entire industry.

After testing our models for various specifications, variables, and time windows, we find the positive effect of innovation performance on inventory turnover to be reasonably robust. Our work has certain limitations that could be addressed in further research. Although we have tested our models with the inventory categories of raw materials, works-in-progress, and finished goods and have obtained consistent results, there are other inventory measures, such as cycle inventory, pipeline inventory, safety stock, and anticipation stock, which may be affected by innovation. Detailed operational data could be useful for understanding the impact of innovation on a variety of inventories. Moreover, our model would 
be enriched by more detailed data on product lines, marketing strategies, competitive status, industry structures, and corporate policies.

We recognize that there are four types of innovation according to the Oslo Manual's definition (Organisation for Economic Co-operation and Development, 2005): product innovation (new or significantly improved products, goods or services), process innovation (new or significantly improved operational processes and service delivery methods), marketing innovation (novel packaging, sales and distribution methods), and managerial innovation (new organizational or managerial methods or processes in business practices, workplace organization or external relations). Although we mainly focus on the first two types based on the classifications used by Scherer (1982, 1984) and Cohen and Klepper (1996a, 1996b), our definition of process innovation also (at least partially) covers the third type (in particular, any innovation in packaging, sales, and distribution methods). To better measure marketing innovation (the third type), we plan to explore the Trademark Database constructed by the U.S. Patent and Trademark Office (see Graham et al., 2013) in future research. Lastly, we also try to use the number of patent inventors in a firm to measure the firm's organizational or managerial innovativeness based on the presumption that people who invented in the past are more likely to experiment and adopt novel managerial and organizational methods and strategies. In an unreported table, we find a significantly positive relation between the number of patent inventors and inventory turnover, even after controlling for innovation performance. This finding strongly supports a distinct positive effect of managerial innovation on inventory management.

\section{Acknowledement}

We thank Guest Editors, Abraham Seidmann, Yabing Jiang, Jie Zhang, and the two anonynous reviewers for their suggestions for improvement during the reviewing process, and UConn seminar participants, 2014 POMS International Conference and $7^{\text {th }}$ CSAMSE conference audience. The work was partially supported by a grant from the General Research Fund (GRF) sponsored by the Research Grants Council 
in Hong Kong (Reference No. HKU 791413B). Po-Hsuan Hsu also acknowledges the support from the General Research Fund sponsored by the Research Grants Council in Hong Kong (Reference No.790913). Any remaining errors are ours.

\section{References}

Anupindi, R., Chopra, S., Deshmukh, S. D., Van Mieghem, J. A., \& Zemel, E. 2011. Managing business process flows: Principles of operations management, $3^{\text {rd }}$ ed. Prentice Hall.

Artz, K. W., Norman, P. M., Hatfield, D. E., \& Cardinal, L. B. 2010. A longitudinal study of the impact of $\mathrm{R} \& \mathrm{D}$, patents, and product innovation on firm performance. Journal of Production Innovation Management, 27(5), 725-740.

Balakrishnan, R., Linsmeier, T. J., \& Venkatachalam, M. 1996. Financial benefits from JIT adoption: Effects of customer concentration and cost structure. Accounting Review, 71(2), 183-205.

Bass, F. M. 1969. A new product growth for model consumer durables. Management Science, 15(5), 215227.

Bernstein, J. I., \& Nadiri, M.I. 1989. Research and development and intra-industry spillovers: An empirical application of dynamic duality. Review of Economic Studies, 56(2), 249-267.

Bhoovaraghavan, S., Vasudevan, A., \& Chandran, R. 1996. Resolving the process vs. product innovation dilemma: A consumer choice theoretic approach. Management Science, 42(2), 232-246.

Cohen, W. M., \& Klepper, S. 1996a. A reprise of size and R \& D. The Economic Journal, 106(437), 925-951.

Cohen, W. M., \& Klepper S. 1996b. Firm size and the nature of innovation within industries: The case of process and product R\&D. The Review of Economics and Statistics, 78(2), 232-243.

Ettlie, J. E., 1995. Product-process development integration in manufacturing. Management Science, 41(7), 1224-1237.

Evenson, R. E., \& Kislev, Y. 1973. Research and productivity in wheat and maize. Journal of Political Economy, 81(6), 1309-1329. 
Fama, E. F., \& French, K. R. 1997. Industry costs of equity. Journal of Financial Economics, 43(2), 153193.

Faraj, S., \& Sproull, L. 2000. Coordinating expertise in software development teams. Management Science, 46(12), 1554-1568.

Gaur, V., Fisher, M. L., \& Raman, A. 2005. An econometric analysis of inventory turnover performance in retail services. Management Science, 51(2), 181-194.

Graham, S. J. H., Hancock, G., Marco, A. C., \& Myers, A. F. 2013. The USPTO trademark case files dataset: descriptions, lessons, and insights. Journal of Economics \& Management Strategy, 22(4), 669705.

Gu, F. 2005. Innovation, future earnings, and market efficiency. Journal of Accounting Auditing and Finance, 20, 385-418.

Gunday, G., Ulusoy, G., Kilic, K., \& Alpkan, L. 2011. Effects of innovation types on firm performance. International Journal of Production Economics, 133, 662-676.

Hirshleifer, D. A., Hsu, P.-H., \& Li, D. 2012. Innovative efficiency and stock returns. Journal of Financial Economics, 107, 632-654.

Hall, B. H., Griliches, Z., \& Hausman, J. 1986. Patents and R and D: Is there a lag? International Economic Review, 27(2), 265-283.

Hall, B. H., Jaffe, A., \& Trajtenberg, M. 2001. The NBER patent citation data files: Lessons, insights and methodological tools. NBER Working Paper 8498, National Bureau of Economic Research, Cambridge, MA.

Hall, B. H., Jaffe, A., \& Trajtenberg, M. 2005. Market value and patent citations. RAND Journal of Economics, 36(1), 16-38.

Hall, R. 1992. The strategic analysis of intangible resources. Strategic Management Journal, 13(2), 135144.

Hausman, J., Hall, B. H., \& Griliches, Z. 1984. Econometric models for count data with an application to the patents-R\&D relationship. Econometrica, 52(4), 909-938. 
Holmstrom, J. 1998. Business process innovation in the supply chain - a case study of implementing vendor managed inventory. European Journal of Purchasing \& Supply Management, 4, 127-131.

Hsu, P.-H. 2009. Technological innovations and aggregate risk premiums. Journal of Financial Economics, 94(2), 264-279.

Huson, M., \& Nanda, D. 1995. The impact of just-in-time manufacturing on firm performance in the US. Journal of Operations Management, 12(3-4), 297-310.

Jaffe, A. B. 1988. Demand and supply influences in R\&D intensity and productivity growth. Review of Economics and Statistics, 70(3), 431-437.

Kaipia, R., \& Tanskanen, K. 2003. Vendor managed category management—an outsourcing solution in retailing. Journal of Purchasing \& Supply Management, 9, 165-175.

Klingenberg, B., Timberlake, R., Geurts, T. G., \& Brown, R. J. 2013. The relationship of operational innovation and financial performance-A critical perspective. International Journal of Production Economics, 142, 317-323.

Kraut, R. E., \& Streeter, L. A. 1995. Coordination in software development. Communications of the ACM, 38(3), 69-81.

Lerner, J. 1994. The importance of patent scope: An empirical analysis. RAND Journal of Economics, 25(2), 319-333.

Lev, B. 2001. Intangibles: Management, Measurement, and Reporting. Washington, DC: Brookings Institution Press.

Li, L. 2012. Effects of enterprise technology on supply chain collaboration: analysis of China-linked supply chain. Enterprise Information Systems, 6(1), 55-77.

Lieberman, M. B., \& Demeester, L. 1999. Inventory reduction and productivity growth: Linkages in the Japanese automotive industry. Management Science, 45(4), 466-485.

Lin, O., \& Mithas, S. 2008. Information technology and inventories: Substitutes or complements? Working paper, University of Maryland, College Park, MD.

Little, J. D. C. 1961. A proof for the queuing formula: L = גW. Operations Research, 9(3), 383-387. 
Manu, F. A., \& Sriram, V. 1996. Innovation, marketing strategy, environment, and performance. Journal of Business Research, 35(1) 79-91.

Matolcsy, Z. P., \& Wyatt A., 2008. The association between technological conditions and the market value of equity. Accounting Review, 83(2), 479-518.

Meyer J., \& Subramaniam M. 2014. Appropriating innovation's technical value: Examining the influence of exploration. Journal of Business Research, 67(1), 2860-2866.

National Science Board, 2010. Science and Engineering Indicators: 2010. Arlington, VA.

Nidumolu, S. 1995. The effect of coordination and uncertainty of software project performance: Residual performance risk as an intervening variable. Information Systems Research, 6(3), 191-219.

Norton, J. A., \& Bass, F. M., 1987. A diffusion theory model of adoption and substitution for successive generations of high-technology products. Management Science, 33(9), 1069-1086.

Oke, A. 2013. Linking manufacturing flexibility to innovation performance in manufacturing plants. International Journal of Production Economics, 143, 242-247.

Olivares, M., \& Cachon, G., 2009. Competing retailers and inventory: An empirical investigation of General Motors’ dealerships in isolated U.S. markets. Management Science, 55(9), 1585-1604.

Organisation for Economic Co-operation and Development. 2005. Oslo Manual. http://www.oecd.org/science/inno/2367580.pdf

Rodgers, E. M. 1995. Diffusion of innovations, $4^{\text {th }}$ ed. New York: Free Press.

Sadikoglu, E., \& Zehir, C. 2010. Investigating the effects of innovation and employee performance on the relationship between total quality management practices and firm performance: An empirical study of Turkish firms. International Journal of Production Economics, 127, 13-26.

Scherer, F. M. 1982. Inter-industry technology flows in the United States. Research Policy, 11(2), 227245.

Scherer, F. M. 1984. Using linked patent and R\&D data to measure inter-industry technology flows. In Z. Griliches (Ed.), R\&D, Patents, and Productivity. Chicago, IL: University of Chicago Press for the National Bureau of Economic Research. 
Schmidt, G. M., \& Porteus, E. L. 2000. The impact of an integrated marketing and manufacturing innovation. Manufacturing and Service Operations Management, 2(4), 317-336.

Shah, R., \& Shin, H. 2007. Relationships among information technology, inventory, and profitability: An investigation of level invariance using sector level data. Journal of Operations Management, 25(4), 768784.

Stevenson, W. J. 2011. Operations Management, $11^{\text {th }}$ ed. New York, NY: McGraw-Hill/Irwin.

Trajtenberg, M., 1990. A penny for your quotes: Patent citations and the value of innovations. RAND Journal of Economics, 21(1), 172-187.

Tsui, E. 2005. The role of IT in KM: Where are we now and where are we heading? Journal of Knowledge Management, 1(1), 3-6.

Wu, D., Greer, M. J., Rosen, D. W., \& Schaefer, D. 2013a. Cloud manufacturing: Strategic vision and state-of-the-art. Journal of Manufacturing Systems, 32(4), 564-579.

Wu, D., Thames, J. L., Rosen, D. W., \& Schaefer, D. 2013b. Enhancing the product realization process with cloud-based design and manufacturing systems. Journal of Computing and Information Science in Engineering, 13(4), 041004.

Yuan, M., Zhang, X., Chen, Z., Vogel, D. R., \& Chu, X. 2009. Antecedents of coordination effectiveness of software developer dyads from interacting teams: An empirical investigation. IEEE Transactions on Engineering Management, 56(3), 494-507.

Zhang, X., Ordonez de Pablos, P., Wang, X., Wang, W., Sun, Y., \& She, J. 2014a. Understanding the users' continuous adoption of 3D social virtual world in China: A comparative case study. Computers in Human Behavior, 35, 578-585.

Zhang, X., Ordonez de Pablos, P., \& Xu, Q. 2014b. Culture effects on the knowledge sharing in multinational virtual classes: A mixed method. Computers in Human Behavior, 31, 491-498.

Zhang, X., Vogel, D. R., \& Zhou, Z. 2012. Effects of information technologies, department characteristics and individual roles on improving knowledge sharing visibility: A qualitative case study. Behavior \& Information Technology, 31(11), 1117-1131. 
TABLE 1: Fama-French 10 industry segments.

\begin{tabular}{l|l}
\hline Industry Classification & Industries \\
\hline Consumer Non-durables & Food, tobacco, textiles, apparel, leather, and toys \\
Consumer Durables & $\begin{array}{l}\text { Cars, TVs, furniture, and household appliances } \\
\text { Machinery, trucks, planes, chemicals, office furniture, paper, and printing }\end{array}$ \\
Energy & Oil, gas, and coal extraction and products \\
HiTech & Computers, software, and electronic equipment \\
Telecommunication & Telephone and television transmission \\
Shops & Wholesale, retail, and some services (laundries and repair shops) \\
Healthcare & Healthcare, medical equipment, and pharmaceutical products \\
Utilities & Electric, gas, natural gas, and water services \\
Others & Mines, construction, building materials, transportation, hotels, business service, entertainment, and finance \\
\hline
\end{tabular}


TABLE 2 : Summary statistics of the variables by the Fama-French 10 industry segments.

\begin{tabular}{|c|c|c|c|c|c|c|c|c|c|c|c|}
\hline $\begin{array}{l}\text { Industry } \\
\text { Classification }\end{array}$ & $\begin{array}{l}\text { Number } \\
\text { of Firms }\end{array}$ & $\begin{array}{c}\text { Number of } \\
\text { Observations }\end{array}$ & $\begin{array}{l}\text { Inventory } \\
\text { Turnover }\end{array}$ & $\begin{array}{c}\text { Patent } \\
\text { Citations }\end{array}$ & $\begin{array}{l}\text { Patent } \\
\text { Counts }\end{array}$ & IEcite & IEcount & $\begin{array}{c}\text { Labor } \\
\text { Productivity }\end{array}$ & $\begin{array}{c}\text { Gross } \\
\text { Margin }\end{array}$ & $\begin{array}{c}\text { Capital } \\
\text { Intensity }\end{array}$ & $\begin{array}{c}\text { Sales } \\
\text { Surprise }\end{array}$ \\
\hline $\begin{array}{l}\text { Consumer Non- } \\
\text { durables }\end{array}$ & 465 & 3,067 & $\begin{array}{c}7.31 \\
(0.60)\end{array}$ & $\begin{array}{l}34.69 \\
(2.22)\end{array}$ & $\begin{array}{c}3.05 \\
(0.18)\end{array}$ & $\begin{array}{c}9.76 \\
(0.88)\end{array}$ & $\begin{array}{c}4.44 \\
(0.54)\end{array}$ & $\begin{array}{l}64.02 \\
(1.63)\end{array}$ & $\begin{array}{c}0.34 \\
(0.00)\end{array}$ & $\begin{array}{c}0.54 \\
(0.00)\end{array}$ & $\begin{array}{c}1.18 \\
(0.04)\end{array}$ \\
\hline $\begin{array}{l}\text { Consumer } \\
\text { Durables }\end{array}$ & 363 & 2,924 & $\begin{array}{c}5.80 \\
(0.08)\end{array}$ & $\begin{array}{l}386.15 \\
(33.31)\end{array}$ & $\begin{array}{l}29.89 \\
(2.28)\end{array}$ & $\begin{array}{l}18.31 \\
(2.31)\end{array}$ & $\begin{array}{c}3.51 \\
(0.41)\end{array}$ & $\begin{array}{l}40.60 \\
(0.72)\end{array}$ & $\begin{array}{c}0.28 \\
(0.00)\end{array}$ & $\begin{array}{c}0.52 \\
(0.00)\end{array}$ & $\begin{array}{c}1.15 \\
(0.03)\end{array}$ \\
\hline Manufacturing & 2,065 & 17,265 & $\begin{array}{c}5.31 \\
(0.13)\end{array}$ & $\begin{array}{l}218.68 \\
(8.92)\end{array}$ & $\begin{array}{l}17.84 \\
(0.63)\end{array}$ & $\begin{array}{l}18.58 \\
(1.64)\end{array}$ & $\begin{array}{c}6.20 \\
(0.33)\end{array}$ & $\begin{array}{l}49.43 \\
(0.39)\end{array}$ & $\begin{array}{c}0.33 \\
(0.00)\end{array}$ & $\begin{array}{c}0.56 \\
(0.00)\end{array}$ & $\begin{array}{c}1.22 \\
(0.03)\end{array}$ \\
\hline Energy & 144 & 1,217 & $\begin{array}{l}11.91 \\
(0.51)\end{array}$ & $\begin{array}{l}387.02 \\
(30.81)\end{array}$ & $\begin{array}{l}30.26 \\
(1.75)\end{array}$ & $\begin{array}{l}10.55 \\
(1.55)\end{array}$ & $\begin{array}{c}6.07 \\
(1.50)\end{array}$ & $\begin{array}{c}299.92 \\
(173.42)\end{array}$ & $\begin{array}{c}0.29 \\
(0.00)\end{array}$ & $\begin{array}{c}0.81 \\
(0.00)\end{array}$ & $\begin{array}{c}1.16 \\
(0.04)\end{array}$ \\
\hline HiTech & 2,115 & 16,567 & $\begin{array}{c}4.74 \\
(0.09)\end{array}$ & $\begin{array}{l}310.06 \\
(15.52)\end{array}$ & $\begin{array}{l}17.96 \\
(0.87)\end{array}$ & $\begin{array}{l}14.69 \\
(0.75)\end{array}$ & $\begin{array}{c}3.97 \\
(0.22)\end{array}$ & $\begin{array}{l}66.76 \\
(0.52)\end{array}$ & $\begin{array}{c}0.42 \\
(0.00)\end{array}$ & $\begin{array}{c}0.47 \\
(0.00)\end{array}$ & $\begin{array}{c}1.44 \\
(0.08)\end{array}$ \\
\hline Shops & 269 & 1,303 & $\begin{array}{c}8.27 \\
(0.66)\end{array}$ & $\begin{array}{l}15.92 \\
(1.98)\end{array}$ & $\begin{array}{c}1.44 \\
(0.16)\end{array}$ & $\begin{array}{l}14.88 \\
(1.57)\end{array}$ & $\begin{array}{c}8.81 \\
(1.12)\end{array}$ & $\begin{array}{l}54.42 \\
(1.62)\end{array}$ & $\begin{array}{c}0.33 \\
(0.00)\end{array}$ & $\begin{array}{c}0.42 \\
(0.01)\end{array}$ & $\begin{array}{c}5.84 \\
(4.12)\end{array}$ \\
\hline Healthcare & 1,152 & 7,563 & $\begin{array}{c}3.72 \\
(0.10)\end{array}$ & $\begin{array}{l}133.51 \\
(6.18)\end{array}$ & $\begin{array}{c}9.10 \\
(0.38)\end{array}$ & $\begin{array}{l}27.41 \\
(2.90)\end{array}$ & $\begin{array}{c}5.10 \\
(0.35)\end{array}$ & $\begin{array}{l}90.49 \\
(1.31)\end{array}$ & $\begin{array}{c}0.52 \\
(0.00)\end{array}$ & $\begin{array}{c}0.52 \\
(0.00)\end{array}$ & $\begin{array}{c}1.65 \\
(0.09)\end{array}$ \\
\hline Others & 122 & 734 & $\begin{array}{l}14.72 \\
(1.63)\end{array}$ & $\begin{array}{l}30.11 \\
(3.56)\end{array}$ & $\begin{array}{c}3.06 \\
(0.40)\end{array}$ & $\begin{array}{l}15.91 \\
(1.88)\end{array}$ & $\begin{array}{c}9.56 \\
(1.40)\end{array}$ & $\begin{array}{c}75.56 \\
(22.79)\end{array}$ & $\begin{array}{c}0.28 \\
(0.00)\end{array}$ & $\begin{array}{c}0.71 \\
(0.01)\end{array}$ & $\begin{array}{c}1.59 \\
(0.38)\end{array}$ \\
\hline All Industries & 6,695 & 50,640 & $\begin{array}{c}5.41 \\
(0.07)\end{array}$ & $\begin{array}{l}230.47 \\
(6.35)\end{array}$ & $\begin{array}{l}16.04 \\
(0.39)\end{array}$ & $\begin{array}{l}17.75 \\
(0.77)\end{array}$ & $\begin{array}{c}5.16 \\
(0.16)\end{array}$ & $\begin{array}{l}68.12 \\
(4.19)\end{array}$ & $\begin{array}{c}0.38 \\
(0.00)\end{array}$ & $\begin{array}{c}0.52 \\
(0.00)\end{array}$ & $\begin{array}{c}1.47 \\
(0.11)\end{array}$ \\
\hline
\end{tabular}

Note: 1 . The numbers above and inside the parentheses are the mean and the standard errors of the variable, respectively.

2. Telecommunication and Utilities are omitted from our dataset and are therefore not shown in the table. 
TABLE 3: Correlation table.

\begin{tabular}{|c|c|c|c|c|c|c|c|c|}
\hline & $\log \left(I T_{\text {sit }}\right)$ & $\log \left(\right.$ IEcite $\left._{\text {sit }}\right)$ & $\log \left(\right.$ IEcite $\left._{\text {sit }-1}\right)$ & $\log \left(\right.$ IEcite $\left._{\text {sit }-2}\right)$ & $\log \left(L P_{\text {sit }}\right)$ & $\log \left(G M_{\text {sit }}\right)$ & $\log \left(C I_{\text {sit }}\right)$ & $\log \left(S S_{\text {sit }}\right)$ \\
\hline $\log \left(I T_{s i t}\right)$ & 1 & & & & & & & \\
\hline $\log \left(\right.$ IEcite $\left._{\text {sit }}\right)$ & -0.045 & 1 & & & & & & \\
\hline $\log \left(\right.$ IEcite $\left._{\text {sit }-1}\right)$ & -0.042 & 0.795 & 1 & & & & & \\
\hline $\log \left(\right.$ IEcite $\left._{\text {sit }-2}\right)$ & -0.041 & 0.725 & 0.784 & 1 & & & & \\
\hline $\log \left(L P_{\text {sit }}\right)$ & -0.023 & -0.277 & -0.250 & -0.223 & 1 & & & \\
\hline $\log \left(G M_{s i t}\right)$ & -0.407 & -0.016 & 0.000 & 0.012 & 0.595 & 1 & & \\
\hline $\log \left(C I_{\text {sit }}\right)$ & 0.447 & -0.081 & -0.063 & -0.050 & 0.030 & -0.046 & 1 & \\
\hline $\log \left(S S_{\text {sit }}\right)$ & 0.124 & 0.031 & 0.016 & -0.007 & 0.067 & 0.053 & -0.040 & 1 \\
\hline
\end{tabular}


TABLE 4: Coefficient estimates for process-focused, product-focused, balanced firms, as well as all firms.

\begin{tabular}{|c|c|c|c|c|c|c|c|c|c|}
\hline & $\begin{array}{c}\text { Process- } \\
\text { focused } \\
\text { Firms } \\
\text { Column (a) }\end{array}$ & $\begin{array}{c}\text { Product- } \\
\text { focused } \\
\text { Firms } \\
\text { Column (b) } \\
\end{array}$ & $\begin{array}{l}\text { Balanced } \\
\text { Firms } \\
\text { Column (c) }\end{array}$ & Column (d) & & $\begin{array}{c}\text { Process- } \\
\text { focused } \\
\text { Firms } \\
\text { Column (e) }\end{array}$ & $\begin{array}{c}\text { Product- } \\
\text { focused } \\
\text { Firms } \\
\text { Column (f) } \\
\end{array}$ & $\begin{array}{l}\text { Balanced } \\
\text { Firms } \\
\text { Column (g) }\end{array}$ & Column (h) \\
\hline $\log \left(\right.$ IEcite $\left._{\text {sit }}\right)$ & $\begin{array}{c}0.016^{* * * *} \\
(0.004)\end{array}$ & $\begin{array}{l}0.004^{*} \\
(0.002)\end{array}$ & $\begin{array}{c}0.006^{* *} \\
(0.003)\end{array}$ & $\begin{array}{c}0.009 * * * \\
(0.002)\end{array}$ & $\log \left(I E\right.$ count $\left._{\text {sit }}\right)$ & $\begin{array}{c}0.046^{* * *} \\
(0.009)\end{array}$ & $\begin{array}{c}0.010 * * \\
(0.005)\end{array}$ & $\begin{array}{c}0.028 * * * \\
(0.006)\end{array}$ & $\begin{array}{c}0.026^{* * *} \\
(0.004)\end{array}$ \\
\hline $\log \left(\right.$ IEcite $\left._{s i, t-1}\right)$ & $\begin{array}{c}0.014^{* * *} \\
(0.004)\end{array}$ & $\begin{array}{l}-0.002 \\
(0.002)\end{array}$ & $\begin{array}{l}-0.001 \\
(0.002)\end{array}$ & $\begin{array}{c}0.004^{* * *} \\
(0.001)\end{array}$ & $\log \left(\right.$ IEcount $\left._{s i, t-1}\right)$ & $\begin{array}{c}0.026^{* * *} \\
(0.006)\end{array}$ & $\begin{array}{c}0.002 \\
(0.004)\end{array}$ & $\begin{array}{c}0.011^{* *} \\
(0.005)\end{array}$ & $\begin{array}{c}0.013 * * * \\
(0.003)\end{array}$ \\
\hline $\log \left(\right.$ IEcite $\left._{s i, t-2}\right)$ & $\begin{array}{c}0.015^{* * *} \\
(0.004)\end{array}$ & $\begin{array}{l}-0.003 \\
(0.003)\end{array}$ & $\begin{array}{c}0.002 \\
(0.002)\end{array}$ & $\begin{array}{c}0.005^{* * *} \\
(0.002)\end{array}$ & $\log \left(I_{E c o u n t}\right.$ si,t-2 $)$ & $\begin{array}{c}0.030 * * * \\
(0.009)\end{array}$ & $\begin{array}{c}0.000 \\
(0.005)\end{array}$ & $\begin{array}{c}0.016^{* * *} \\
(0.006)\end{array}$ & $\begin{array}{c}0.013^{* * *} \\
(0.004)\end{array}$ \\
\hline $\log \left(L P_{\text {sit }}\right)$ & $\begin{array}{c}0.307^{* * *} \\
(0.035)\end{array}$ & $\begin{array}{c}0.336^{* * *} \\
(0.031)\end{array}$ & $\begin{array}{c}0.372 * * * \\
(0.038)\end{array}$ & $\begin{array}{c}0.361^{* * *} \\
(0.018)\end{array}$ & $\log \left(L P_{\text {sit }}\right)$ & $\begin{array}{c}0.314^{* * *} \\
(0.034)\end{array}$ & $\begin{array}{c}0.337 * * * \\
(0.031)\end{array}$ & $\begin{array}{c}0.379 * * * \\
(0.037)\end{array}$ & $\begin{array}{c}0.365^{* * *} \\
(0.018)\end{array}$ \\
\hline $\log \left(G M_{s i t}\right)$ & $\begin{array}{c}-0.584^{* * *} \\
(0.060)\end{array}$ & $\begin{array}{c}-0.783^{* * *} \\
(0.051)\end{array}$ & $\begin{array}{c}-0.616^{* * *} \\
(0.055)\end{array}$ & $\begin{array}{c}-0.667^{* * *} \\
(0.028)\end{array}$ & $\log \left(G M_{\text {sit }}\right)$ & $\begin{array}{c}-0.583 * * * \\
(0.059)\end{array}$ & $\begin{array}{c}-0.782^{* * *} \\
(0.051)\end{array}$ & $\begin{array}{c}-0.623^{* * *} \\
(0.055)\end{array}$ & $\begin{array}{c}-0.668 * * * \\
(0.028)\end{array}$ \\
\hline $\log \left(C I_{s i t}\right)$ & $\begin{array}{c}0.340^{* * *} \\
(0.044)\end{array}$ & $\begin{array}{c}0.618 * * * \\
(0.055)\end{array}$ & $\begin{array}{c}0.399 * * * \\
(0.035)\end{array}$ & $\begin{array}{c}0.392 * * * \\
(0.022)\end{array}$ & $\log \left(C I_{\text {sit }}\right)$ & $\begin{array}{c}0.353^{* * *} \\
(0.043)\end{array}$ & $\begin{array}{c}0.617 * * * \\
(0.055)\end{array}$ & $\begin{array}{c}0.409 * * * \\
(0.035)\end{array}$ & $\begin{array}{c}0.398 * * * \\
(0.022)\end{array}$ \\
\hline $\log \left(S S_{s i t}\right)$ & $\begin{array}{c}0.259 * * * \\
(0.022)\end{array}$ & $\begin{array}{c}0.272^{* * *} \\
(0.027)\end{array}$ & $\begin{array}{c}0.248^{* * *} \\
(0.020)\end{array}$ & $\begin{array}{c}0.272^{* * *} \\
(0.013)\end{array}$ & $\log \left(S S_{\text {sit }}\right)$ & $\begin{array}{c}0.247 * * * \\
(0.022)\end{array}$ & $\begin{array}{c}0.269 * * * \\
(0.027)\end{array}$ & $\begin{array}{c}0.236^{* * *} \\
(0.019)\end{array}$ & $\begin{array}{c}0.265^{* * *} \\
(0.013)\end{array}$ \\
\hline Firm $\mathrm{F}$ & Yes & Yes & Yes & Yes & Firm Fixed Effect & Yes & Yes & Yes & Yes \\
\hline No. of Firms & 882 & 1,147 & 1,054 & 4,569 & No. of Firms & 882 & 1,147 & 1,054 & 4,569 \\
\hline Yearly Effect & Yes & Yes & Yes & Yes & Yearly Effect & Yes & Yes & Yes & Yes \\
\hline No. of Observations & 7,868 & 13,986 & 10,539 & 40,906 & No. of Observations & 7,868 & 13,986 & 10,539 & 40,906 \\
\hline Adj. $R$-squared & $73.6 \%$ & $84.8 \%$ & $80.7 \%$ & $81.9 \%$ & Adj. $R$-squared & $79.1 \%$ & $84.8 \%$ & $80.9 \%$ & $82.1 \%$ \\
\hline
\end{tabular}

Note: The numbers in the parentheses represent the robust standard errors of the variables. We use panel regression with heteroskedasticity and autocorrelation to estimate the coefficients for the model in Equation (1) by the three groups and all firms in Columns (a) to (d), and the coefficients for the model in Equation (1) (after replacing the citation-based measures with the count-based measures) by the three groups and all firms in Columns (e) to (h). In the interests of brevity, we do not report the coefficients for the firm and yearly fixed effects.

$*, * *, * * *$ Statistically significant $p<10 \%, p<5 \%$, and $p<1 \%$, respectively, for two-tailed tests. 
TABLE 5: Coefficient estimates for the subgroup analysis.

\begin{tabular}{|c|c|c|c|c|c|c|c|c|}
\hline & & & & & & & & \\
\hline & All Firms & $\begin{array}{l}\text { Consumer Non- } \\
\text { durables }\end{array}$ & $\begin{array}{l}\text { Consumer } \\
\text { Durables }\end{array}$ & Manufacturing & Energy & HiTech & Shops & Healthcare \\
\hline $\log \left(\right.$ IEcite $\left._{\text {sit }}\right)$ & $\begin{array}{c}0.009^{* * *} \\
(0.002)\end{array}$ & $\begin{array}{c}-0.013^{* *} \\
(0.006)\end{array}$ & $\begin{array}{l}-0.002 \\
(0.004)\end{array}$ & $\begin{array}{l}0.005^{*} \\
(0.003)\end{array}$ & $\begin{array}{c}0.008 \\
(0.012)\end{array}$ & $\begin{array}{c}0.009 * * * \\
(0.003)\end{array}$ & $\begin{array}{c}0.053^{* * *} \\
(0.016)\end{array}$ & $\begin{array}{c}0.017^{* * *} \\
(0.004)\end{array}$ \\
\hline $\log \left(\right.$ IEcite $\left._{s i, t-1}\right)$ & $\begin{array}{c}0.004^{* * *} \\
(0.001)\end{array}$ & $\begin{array}{c}-0.015^{*} \\
(0.009)\end{array}$ & $\begin{array}{c}0.009 * * \\
(0.004)\end{array}$ & $\begin{array}{c}0.001 \\
(0.002)\end{array}$ & $\begin{array}{l}-0.011 \\
(0.009)\end{array}$ & $\begin{array}{c}0.004 \\
(0.003)\end{array}$ & $\begin{array}{c}0.022^{* *} \\
(0.009)\end{array}$ & $\begin{array}{c}0.007^{* *} \\
(0.004)\end{array}$ \\
\hline $\log \left(\right.$ IEcite $\left._{s i, t-2}\right)$ & $\begin{array}{c}0.005^{* * *} \\
(0.002)\end{array}$ & $\begin{array}{c}-0.013 \\
(0.008)\end{array}$ & $\begin{array}{c}0.010^{* *} \\
(0.004)\end{array}$ & $\begin{array}{c}0.003 \\
(0.003)\end{array}$ & $\begin{array}{c}0.001 \\
(0.013)\end{array}$ & $\begin{array}{c}0.006 * \\
(0.003)\end{array}$ & $\begin{array}{c}0.015 \\
(0.011)\end{array}$ & $\begin{array}{c}0.005 \\
(0.004)\end{array}$ \\
\hline $\log \left(L P_{\text {sit }}\right)$ & $\begin{array}{c}0.361^{* * *} \\
(0.018)\end{array}$ & $\begin{array}{c}0.191^{* * *} \\
(0.064)\end{array}$ & $\begin{array}{c}0.357 * * * \\
(0.069)\end{array}$ & $\begin{array}{c}0.388^{* * *} \\
(0.044)\end{array}$ & $\begin{array}{c}0.263 * * \\
(0.121)\end{array}$ & $\begin{array}{c}0.355^{* * *} \\
(0.028)\end{array}$ & $\begin{array}{c}0.310 * * * \\
(0.074)\end{array}$ & $\begin{array}{c}0.445^{* * *} \\
(0.035)\end{array}$ \\
\hline $\log \left(G M_{\text {sit }}\right)$ & $\begin{array}{c}-0.667 * * * \\
(0.028)\end{array}$ & $\begin{array}{c}-0.429 * * * \\
(0.069)\end{array}$ & $\begin{array}{c}-0.464^{* * *} \\
(0.085)\end{array}$ & $\begin{array}{c}-0.603^{* * *} \\
(0.062)\end{array}$ & $\begin{array}{c}-0.408^{* *} \\
(0.181)\end{array}$ & $\begin{array}{c}-0.632 * * * \\
(0.045)\end{array}$ & $\begin{array}{c}-0.631^{* * *} \\
(0.093)\end{array}$ & $\begin{array}{c}-0.967 * * * \\
(0.058)\end{array}$ \\
\hline $\log \left(C I_{\text {sit }}\right)$ & $\begin{array}{c}0.392 * * * \\
(0.022)\end{array}$ & $\begin{array}{c}0.531^{* * *} \\
(0.077)\end{array}$ & $\begin{array}{c}0.546 * * * \\
(0.086)\end{array}$ & $\begin{array}{c}0.470 * * * \\
(0.039)\end{array}$ & $\begin{array}{c}0.428 * * \\
(0.201)\end{array}$ & $\begin{array}{c}0.400 * * * \\
(0.038)\end{array}$ & $\begin{array}{c}0.244 * * * \\
(0.049)\end{array}$ & $\begin{array}{c}0.309 * * * \\
(0.036)\end{array}$ \\
\hline $\log \left(S S_{s i t}\right)$ & $\begin{array}{c}0.272 * * * \\
(0.013)\end{array}$ & $\begin{array}{c}0.232^{* * *} \\
(0.040)\end{array}$ & $\begin{array}{c}0.280^{* * *} \\
(0.038)\end{array}$ & $\begin{array}{c}0.244^{* * *} \\
(0.020)\end{array}$ & $\begin{array}{c}0.410^{* * *} \\
(0.141)\end{array}$ & $\begin{array}{c}0.265^{* * *} \\
(0.018)\end{array}$ & $\begin{array}{c}0.362 * * * \\
(0.052)\end{array}$ & $\begin{array}{c}0.235^{* * *} \\
(0.029)\end{array}$ \\
\hline Firm Fixed Effect & Yes & Yes & Yes & Yes & Yes & Yes & Yes & Yes \\
\hline No. of Firms & 4,569 & 330 & 247 & 1,465 & 101 & 1,489 & 150 & 703 \\
\hline Yearly Effect & Yes & Yes & Yes & Yes & Yes & Yes & Yes & Yes \\
\hline No. of Observations & 40,906 & 2,466 & 2,437 & 14,596 & 1,032 & 13,230 & 928 & 5,646 \\
\hline Adj. $R$-squared & $81.9 \%$ & $89.0 \%$ & $86.6 \%$ & $82.4 \%$ & $83.9 \%$ & $75.9 \%$ & $86.7 \%$ & $74.3 \%$ \\
\hline
\end{tabular}

Note: The numbers in the parentheses represent the robust standard errors of the variables. We use panel regression with heteroskedasticity and autocorrelation to estimate the coefficients for the models with innovation variables, that is, $\log \left(I_{\text {c cite }} i, t-j\right)$ for $j=0,1,2$, by the Fama-French 10 industry segments (see Table 1 for details). In the interests of brevity, we do not report the coefficients for the firm and yearly fixed effects.

$*, * *, * * *$ Statistically significant $p<10 \%, p<5 \%$, and $p<1 \%$, respectively, for two-tailed tests. 
TABLE 6: Coefficient estimates for the innovation spillover effect.

\begin{tabular}{|c|c|c|c|c|}
\hline & All Firms & $\begin{array}{l}\text { Process- } \\
\text { focused } \\
\text { Firms }\end{array}$ & $\begin{array}{l}\text { Product- } \\
\text { focused } \\
\text { Firms }\end{array}$ & $\begin{array}{c}\text { Balanced } \\
\text { Firms }\end{array}$ \\
\hline & Column (a) & Column (b) & Column (c) & Column (d) \\
\hline \multirow{2}{*}{$\log \left(\right.$ IEcite $\left._{s t}\right)$} & $0.012 * *$ & $0.028 * *$ & 0.010 & 0.011 \\
\hline & $(0.005)$ & $(0.013)$ & $(0.007)$ & $(0.010)$ \\
\hline \multirow{2}{*}{$\log \left(\right.$ IEcite $\left._{s, t-1}\right)$} & 0.008 & 0.009 & 0.012 & 0.007 \\
\hline & $(0.007)$ & $(0.018)$ & $(0.011)$ & $(0.016)$ \\
\hline \multirow{2}{*}{$\log \left(\right.$ IEcite $\left._{s, t-2}\right)$} & -0.001 & -0.005 & $0.034^{* *}$ & -0.017 \\
\hline & $(0.009)$ & $(0.023)$ & $(0.015)$ & $(0.022)$ \\
\hline \multirow{2}{*}{$\log \left(\right.$ IEcite $\left._{\text {sit }}\right)$} & $0.009 * * *$ & $0.015 * * *$ & 0.004 & $0.006^{* *}$ \\
\hline & $(0.002)$ & $(0.004)$ & $(0.002)$ & $(0.003)$ \\
\hline \multirow{2}{*}{$\log \left(\right.$ IEcite $\left._{s i, t-1}\right)$} & $0.004 * * *$ & $0.013^{* * *}$ & -0.003 & -0.001 \\
\hline & $(0.001)$ & $(0.003)$ & $(0.002)$ & $(0.002)$ \\
\hline \multirow{2}{*}{$\log \left(\right.$ IEcite $\left._{s i, t-2}\right)$} & $0.005 * * *$ & $0.014 * * *$ & -0.004 & 0.002 \\
\hline & $(0.002)$ & $(0.004)$ & $(0.003)$ & $(0.002)$ \\
\hline \multirow{2}{*}{$\log \left(L P_{\text {sit }}\right)$} & $0.362 * * *$ & $0.307 * * *$ & $0.337 * * *$ & $0.373 * * *$ \\
\hline & $(0.018)$ & $(0.034)$ & $(0.031)$ & (0.038) \\
\hline \multirow{2}{*}{$\log \left(G M_{s i t}\right)$} & $-0.667 * * *$ & $-0.583 * * *$ & $-0.780 * * *$ & $-0.617 * * *$ \\
\hline & $(0.028)$ & $(0.060)$ & $(0.051)$ & $(0.055)$ \\
\hline \multirow{2}{*}{$\log \left(C I_{\text {sit }}\right)$} & $0.393 * * *$ & $0.341^{* * *}$ & $0.620 * * *$ & $0.399 * * *$ \\
\hline & $(0.022)$ & $(0.044)$ & $(0.055)$ & $(0.035)$ \\
\hline \multirow{2}{*}{$\log \left(S S_{\text {sit }}\right)$} & $0.272 * * *$ & $0.258 * * *$ & $0.271^{* * *}$ & $0.248 * * *$ \\
\hline & $(0.013)$ & $(0.022)$ & $(0.027)$ & $(0.020)$ \\
\hline \multirow{4}{*}{$\begin{array}{l}\text { Firm Fixed } \\
\text { Effect } \\
\text { No. of Firms } \\
\text { Yearly Effect } \\
\text { No. of } \\
\text { Observations }\end{array}$} & Yes & Yes & Yes & Yes \\
\hline & 4,569 & 882 & 1,147 & 1,054 \\
\hline & Yes & Yes & Yes & Yes \\
\hline & 40,906 & 7,533 & 13986 & 10,539 \\
\hline Adj. $R$-squared & $81.9 \%$ & $78.7 \%$ & $84.8 \%$ & $80.7 \%$ \\
\hline
\end{tabular}

Note: The numbers in the parentheses represent the robust standard errors of the variables. We use panel regression with heteroskedasticity and autocorrelation to estimate the coefficients for the model in Equation (2) for all firms (column a), and for the model by the three firm groups (columns b to d). In the interests of brevity, we do not report the coefficients for the firm and yearly fixed effects.

$*$, **, *** Statistically significant $p<10 \%, p<5 \%$, and $p<1 \%$, respectively, for two-tailed tests. 